\title{
PENGARUH PENGGANTIAN TEPUNG IKAN DENGAN SUSU AFKIR DALAM RANSUM TERHADAP PERFORMA PRODUKSI DAN KECERNAAN NUTRIEN AYAM BURAS JANTAN
}

\author{
PERTIWI, M. E. D*., I M. MASTIKA**, DAN I M. NURIYASA** \\ *Program Studi Magister Ilmu Peternakan \\ **Fakultas Peternakan, Universitas Udayana, Denpasar \\ e-mail: marliana.esti@gmail.com
}

\begin{abstract}
ABSTRAK
Penelitian ini bertujuan untuk mengetahui pengaruh penggantian tepung ikan dengan susu afkir dalam ransum terhadap performa dan kecernaan nutrien ayam buras umur 2-10 minggu. Penelitian lapangan dilaksanakan di Desa Puger, Kabupaten Jember, Jawa Timur. Rancangan yang digunakan adalah Rancangan Acak Lengkap (RAL) dengan lima perlakuan dan lima ulangan sehingga terdapat 25 unit percobaan, setiap unit percobaan terdiri dari empat ekor ayam buras jantan. Perlakuan adalah ransum tanpa penggantian tepung ikan (Ro); ransum pengantian 25\% tepung ikan dengan susu afkir (R1); ransum pengantian 50\% tepung ikan dengan susu afkir (R2); ransum pengantian $75 \%$ tepung ikan dengan susu afkir (R3) dan ransum pengantian 100\% tepung ikan dengan susu afkir (R4). Ransum dan air minum diberikan secara ad libitum. Variabel yang diamati adalah performa produksi dan kecernaan nutrien. Hasil penelitian menunjukkan bahwa ayam buras yang diberikan ransum penggantian tepung ikan dengan susu afkir 75\% ( $\left.\mathrm{R}_{3}\right)$ menghasilkan performa dan kecernaan nutrien nyata lebih tinggi $(\mathrm{P}<0,05)$ dibandingkan perlakuan Ro, R1, R2 dan R4. Perlakuan R3 menghasilkan koefisien cerna bahan kering 75,08\% dan koefisien cerna protein kasar 72,21\%. Dari hasil penelitian dapat disimpulkan bahwa penggantian tepung ikan dengan susu afkir pada aras $75 \%$ menghasilkan performa produksi dan kecernaan nutrien lebih baik dari perlakuan lainnya.
\end{abstract}

Kata kunci: ayam buras, susu afkir, performa, kecernaan nutrien

\section{THE EFFECT OF FISH MEAL REPLACEMENT WITH EXPIRED POWDER MILK IN RATIONS ON THE PERFORMANCE AND NUTRIENT DIGESTIBILITY OF MALE NATIVE CHICKENS (2-10 WEEKS)}

\begin{abstract}
The purpose of this study is to determine the effect of fish meal substitution with expired milk in diets on the productivity of cockerels at the age of 2-10 weeks. This study was carried out in Puger Village, Jember Regency, East Java. A Completely Randomized Design (CRD) was used with five treatments and five replicates. Totally, there were 25 experimental units and each unit consists of four cockerels fed without fish meal (Ro); $25 \%$ diets of fish meal substitution with expired milk (R1); 50\% diets of fish meal substitution with expired milk (R2); $75 \%$ diets of fish meal substitution with expired milk (R3) and 100\% diets of fish meal substitution with expired milk (R4). Diets and water were given ad libitum. The variables observed were performance and nutrient digestibility. It showed that cockerels fed $75 \%$ diets of fish meal substitution with expired milk (R3) produced higher final body weight and nutrient digestibility $(\mathrm{P}<0.05)$ compared to treatment Ro, R1, R2 and R4. Treatment $\mathrm{R} 3$ produced 75.08\% digestibility coefficient of dry ingredient and $72,21 \%$ digestibility coefficient of crude protein. It can be concluded that $75 \%$ fish meal substitution with expired milk produced better performance and nutrient digestibility compared to other treatment.
\end{abstract}

Keyword: cockerels, expired milk, performance, digestibility of nutrient 


\section{PENDAHULUAN}

Ayam buras merupakan ayam lokal Indonesia yang pada umumnya sering dipelihara oleh masyarakat petani. Selain dagingnya yang khas, telur ayam buras juga sangat diminati dan mampu memenuhi kebutuhan protein hewani masyarakat. Ayam buras memiliki fungsi strategis dalam meningkatkan nilai gizi masyarakat, pemenuhan pangan dan berpotensi meningkatkan pendapatan masyarakat (Pusdatin, 2015).

Permasalahan peternak yang dihadapi saat ini adalah harga pakan dari hari ke hari semakin mahal, sedangkan kualitas dari bahan pakan yang ada semakin menurun. Ketersediaan tepung ikan untuk bahan pakan ternak sangat banyak namun tepung ikan dengan kualitas baik harganya sangat tinggi. Pada kondisi seperti itu peternak harus mampu mengganti seluruh atau sebagian bahan-bahan yang diperlukan serta mampu memanfaatkan limbah hasil industri seperti susu afkir yang kaya akan kandungan gizi dan protein yang mampu meningkatkan pertumbuhan ayam buras lebih optimal.

Limbah susu bubuk afkir merupakan susu yang sudah tidak dipakai atau tidak dikonsumsi lagi oleh manusia. Susu bubuk afkir adalah sisa-sisa susu bubuk yang menempel pada alat mesin atau juga bisa susu bubuk yang sudah kadaluarsa namun kadar nutrisinya tidak jauh berbeda dengan susu yang tidak diafkir (Irianto, 2011). Disisi lain, susu afkir dapat digunakan sebagai bahan pakan ternak karena mengandung protein 25,8\%, lemak 0,9\%, laktosa 4,6\% kandungan nutrien lainnya seperti natrium, kalium, vitamin, mineral dan asam amino (Alim et al., 2012).

Susu afkir memenuhi persyaratan sebagai pakan tambahan maupun pengganti bahan baku ransum pada ayam buras yaitu bahan mudah didapatkan, harga relatif terjangkau, tidak bersaing dengan kebutuhan manusia dan komposisi nutrien berkualitas dengan kandungan protein tinggi. Alim et al. (2012) menyatakan bahwa penambahan susu afkir sebesar 5\%, 7.5\%, dan 10\% dari total ransum memberikan bobot yang semakin tinggi dibandingkan ransum komersial tanpa penambahan susu afkir. Penambahan susu afkir sebesar 10\% dari total ransum memberikan hasil terbaik terhadap peningkatan konsumsi pakan.

Susuafkirdapatmenjadialternatifuntukpenggantian tepung ikan dalam komposisi ransum karena harga yang relatif murah dibandingkan tepung ikan. Penggantian tepung ikan dengan menggunakan susu afkir diharapkan mampu meningkatkan penampilan ayam buras dengan efisiensi penggunaan pakan yang tinggi. Sampai saat ini beberapa peneliti seperti Alim et al. (2012) dan Nanda (2012) telah melakukan penelitian dengan menggunakan susu afkir terhadap ayam ras, namun belum terdapat penelitian untuk ayam buras serta dilakukan dengan cara penggantian tepung ikan dengan susu afkir. Berdasarkan hal tersebut perlu dilakukan penelitian mengenai penggantian bahan dari tepung ikan dengan menggunakan susu afkir untuk meningkatkan profuktivitas pada ayam buras.

\section{MATERI DAN METODE}

\section{Ayam dan Ransum}

Materi yang digunakan dalam penelitian ini adalah ayam buras umur satu hari (DOC) yang diperoleh dari perusahaan lokal Kediri, Jawa Timur sebanyak 100 ekor dengan kondisi berat badan yang homogen. Ayam buras umur satu hari dipelihara hingga umur dua minggu sebelum pengambilan data yang dilakukan di kandang pribadi di Desa Puger, Kecamatan Puger, Kabupaten Jember, Jawa Timur berlangsung selama dua bulan.

Ransum percobaan disusun berdasarkan perlakuan yang digunakan yaitu dengan penggantian tepung ikan dengan susu afkir o\%, 25\%, 50\%, 75\% dan 100\% dengan lima pengulangan. Kandungan ransum dalam penelitian ini protein $18 \%$ dan energi termetabolis $2900 \mathrm{kkal} /$ kg (Zainudin, 2000 dan Gunawan, 2003). Pemberian pakan dan air minum diberikan dua kali dalam sehari secara ad libitum.

\section{Rancangan Percobaan}

Rancangan yang digunakan dalam penelitian ini adalah rancangan acak lengkap (RAL) dengan lima (5) perlakuan dan lima (5) ulangan, masing-masing unit percobaan terdiri atas empat (4) ekor ayam buras jantan, sehingga jumlah ayam buras jantan yang digunakan adalah 100 ekor. Perlakuan yang digunakan dalam penelitian ini adalah ransum kontrol tanpa penggantian tepung ikan (Ro); ransum dengan pengantian 25\% tepung ikan dengan susu afkir (R1); ransum dengan pengantian 50\% tepung ikan dengan susu afkir (R2); ransum dengan pengantian $75 \%$ tepung ikan dengan susu afkir ( $\mathrm{R}_{3}$ ); ransum dengan pengantian 100\% tepung ikan dengan susu afkir (R4).

\section{Kecernaan Nutrien}

Kecernaan nutrien dihitung dengan metode koleksi total (Tillman et al., 1989). Koleksi total dilakukan selama satu minggu pada ayam yang berumur 10 minggu. Ekskreta ditampung dan dijemur dibawah sinar matahari sampai kering udara, kemudian dioven pada suhu $\left(100-105^{\circ} \mathrm{C}\right)$ selama lima jam sampai ekskreta kering. Kandungan energi ekskreta dapat ditentukan dengan bomb calorimeter dan protein ekskreta ditentukan dengan analisa Kjelldhal menurut metoda AOAC (1984). Kecernaan bahan kering dihitung dengan : 


$$
\mathrm{KCBK}=\frac{(\mathrm{A}-\mathrm{B})}{\mathrm{A}} \times 100 \%
$$

Keterangan :

KCBK : Koefisien cerna bahan kering pakan (\%)

A : Konsumsi bahan kering pakan (g)

B : Jumlah bahan kering ekskreta (g)

Efisiensi perubahan GE menjadi DE dapat dihitung berdasarkan metode koleksi total (Prasad et al., 1996). Efisiensi GE menjadi DE dihitung dengan menggunakan formulasi :

$$
\mathrm{DE} / \mathrm{GE}=\frac{(\mathrm{A}-\mathrm{B})}{\mathrm{A}} \times 100 \%
$$

Keterangan :

DE/GE : Efisiensi GE menjadi DE (\%)

A : Konsumsi energi (kkal/hari)

B : Kandungan energi dalam feses (kkal/hari)

Kecernaan protein kasar pakan dihitung dengan metode koleksi total (Tillman et al., 1989). Koefisien cerna protein dihitung dengan formula:

$$
\mathrm{KCBK}=\frac{(\mathrm{A}-\mathrm{B})}{\mathrm{A}} \times 100 \%
$$

Keterangan :

$\begin{array}{ll}\text { KCPK } & \text { : Koefisien cerna protein kasar (\%) } \\ \text { A } & \text { : Konsumsi protein (g) } \\ \text { B } & \text { : Jumlah protein ekskreta (g) }\end{array}$

Variabel yang diamati dalam penelitian ini yaitu performa yang meliputi berat badan awal, berat badan akhir, pertambahan berat badan, konsumsi ransum serta konversi ransum dan kecernaan nutrien meliputi koefisien cerna bahan kering, efisiensi perubahan GE menjadi DE, koefisiensi cerna protein kasar. Data yang diperoleh dari penelitian ini dianalisa dengan analisis sidik ragam program SPSS 22, apabila diantara perlakuan ada yang berbeda nyata maka dilanjutkan dengan uji jarak berganda dari Duncan (Steel and Torrie, 1991).

\section{HASIL DAN PEMBAHASAN}

\section{Berat Badan Ayam}

Hasil penelitian menunjukkan tidak terjadi perbedaan yang nyata $(\mathrm{P}>0,05)$ pada semua perlakuan terhadap variabel berat badan awal ayam buras. Hal ini menunjukkan bahwa ayam buras yang digunakan dalam penelitian adalah homogen. Berat badan akhir dipengaruhi oleh jumlah pakan yang dikonsumsi dan kandungan nutrien yang dikonsumsi ayam buras. Kandungan nutrien yang diserap lebih banyak oleh ayam buras akan memberikan berat badan akhir lebih tinggi, karena perkembangan jaringan dan lemak banyak dilakukan oleh ayam (Ariesta, 2015).

Ayam buras yang mendapatkan perlakuan ransum R3 menghasilkan berat badan akhir paling tinggi yaitu 1136,6 g/ekor, sedangkan ayam yang diberi ransum Ro, R1, R2 dan R4 menghasilkan berat badan akhir masingmasing 7,86\%; 4,59\%; 4,49\% dan 16,29\% yang nyata $(\mathrm{P}<0,05)$ lebih rendah dari perlakuan $\mathrm{R} 3$. Hal tersebut disebabkan karena konsumsi energi sebesar 176,77 $\mathrm{kkal} /$ hari dan konsumsi protein sebesar 12,74 g/hari lebih tinggi dari perlakuan Ro, R1, R2 dan R4 masingmasing konsumsi energi 174,08 kkal/hari; 174,26 kkal/ hari; 174,30 kkal/hari; 160,70 kkal/hari dan konsumsi protein 11,34 g/hari; 11,99 g/hari; 11,52g/hari dan 10,78 $\mathrm{g} /$ hari. Energi dan protein merupakan komponen pokok sehingga memungkinkan dalam pembentukan jaringan tubuh ayam buras lebih baik. Sejalan dengan penelitian Dewi et al. (2011) bahwa ayam buras yang diberi ransum mengandung imbangan energi dan protein lebih tinggi menghasilkan berat badan lebih tinggi.

\section{Pertambahan Bobot Badan}

Pertambahan bobot badan ayam buras paling tinggi terjadi pada perlakuan ransum $\mathrm{R}_{3}$ yaitu 16,03 g/ekor/ hari. Perlakuan R4 menghasilkan pertambahan berat badan yaitu $19,46 \%$ nyata $(\mathrm{P}<0,05)$ lebih rendah dari perlakuan R3. Penelitian ini sejalan dengan pendapat Alim et al. (2012) mengemukakan bahwa susu afkir dapat meningkatkan konsumsi pakan dan memiliki palatabilitas tinggi sehingga pakan yang diberikan dengan tambahan susu afkir sebagian besar bisa tercerna dengan baik dan berdampak pada peningkatan pertambahan berat badan ayam pedaging. Perlakuan ransum R4 menghasilkan pertambahan berat badan yaitu 12,91 g nyata $(\mathrm{P}<0,05)$ lebih rendah dari perlakuan $\mathrm{R}_{3}$. Hal ini disebabkan karena konsumsi ransum yang rendah, selain itu disebabkan bentuk pakan seperti tepung sehingga sulit dipatuk oleh ayam yang menyebabkan konsumsi rendah dan pertambahan bobot badan kurang maksimal. Nilai koefisien cerna protein kasar yang cenderung menurun menyebabkan protein yang diserap oleh tubuh ayam buras menjadi lebih rendah, sehingga menyebabkan rendahnya pertambahan berat badan pada perlakuan R4.

\section{Konsumsi Ransum}

Konsumsi ransum tertinggi terjadi pada ayam buras yang mendapatkan perlakuan R3 yaitu 46,74 g/hari. Ayam buras yang mendapatkan perlakuan Ro, R1, dan R2 masing-masing adalah 5,48\%; 3,83\% dan 1,90\% lebih rendah $(\mathrm{P}>0,05)$ dari perlakuan $\mathrm{R} 3$. Perlakuan R4 menghasilkan konsumsi ransum ayam buras 11,94\% lebih rendah dari perlakuan $\mathrm{R}_{3}$ yang secara statistik menunjukkan berbeda nyata $(\mathrm{P}<\mathrm{O}, 05)$. Hal tersebut 
Tabel 1. Performa produksi ayam buras jantan yang diberi perlakuan penggantian tepung ikan dengan susu afkir dalam ransum umur $2-10$ minggu

\begin{tabular}{|c|c|c|c|c|c|c|}
\hline \multirow{2}{*}{ Peubah } & \multicolumn{5}{|c|}{ Pelakuan $^{1)}$} & \multirow{2}{*}{ SEM $^{2)}$} \\
\hline & RO & R1 & $\mathrm{R} 2$ & R3 & R4 & \\
\hline Berat badan awal (g/ekor) & $172,95^{a}$ & $173,95^{a}$ & $172,9^{a}$ & $175^{a}$ & $176,7^{a}$ & 4,01 \\
\hline Berat badan akhir (g/ekor) & $1047,2^{a b}$ & $1084,4^{a b}$ & $1085,6^{a b}$ & $1136,6^{\mathrm{a}}$ & $951,45^{b}$ & 42,53 \\
\hline Pertambahan bobot badan (g/ekor/hari) & $14,57^{\mathrm{ab}}$ & $15,18^{a}$ & $15,21^{a}$ & $16,03^{a}$ & $12,91^{\mathrm{b}}$ & 0,67 \\
\hline Konsumsi ransum (g/ekor/hari) & $44,18^{a b 3)}$ & $44,95^{a b}$ & $45,85^{a}$ & $46,74^{a}$ & $41,16^{b}$ & 1,41 \\
\hline Konversi ransum (FCR) & $3,06^{a}$ & $2,97^{a}$ & $3,02^{a}$ & $2,96^{a}$ & $3,19^{b}$ & 0,12 \\
\hline
\end{tabular}

Keterangan :

Perlakuan ransum kontrol tanpa penggantian tepung ikan (R0); penggantian 25\% (R1); penggantian 50\% (R2); penggantian 75\% (R3); penggantian 100\% (R4)

Standard Error of the Treatment Means

Huruf superskrip huruf yang berbeda pada baris yang sama menunjukkan perbedaan yang nyata $(P<0,05)$

disebabkan karena palatabilitas ransum R3 lebih tinggi sehingga konsumsi ransum ayam buras pada perlakuan tersebut lebih tinggi. Seperti yang dinyatakan Kartadisastra (1997) bahwa palatabilitas merupakan sifat performa dari bahan-bahan sebagai akibat dari keadaan fisik dan kimiawi yang dimiliki bahan-bahan tersebut. Lebih lanjut dinyatakan oleh Wahju (2015) perbedaan konsumsi ransum dipengaruhi oleh kualitas ransum, palatabilitas ransum dan pengolahannya. Selain itu, Setiadi (2012) menyatakan bahwa tingkat konsumsi ransum akan mempengaruhi laju pertumbuhan dan bobot akhir karena pembentukan bobot, bentuk dan komposisi tubuh pada hakekatnya adalah akumulasi pakan yang dikonsumsi kedalam tubuh ternak.

\section{Feed Convertion Ratio (FCR)}

Nilai feed convertion ratio (FCR) atau konversi ransum merupakan tolak ukur untuk menentukan tingkat efisiensi jumlah penggunaan pakan. Menurut Rasyaf (1995) semakin rendah angka FCR makan semakin tinggi efisiensi penggunaan ransumnya, demikian pula sebaliknya. Tabel 1 menunjukkan bahwa konversi ransum paling rendah terjadi pada perlakuan R3 yaitu 2,96. Sejalan dengan pendapat Alim et al. (2012) bahwa susu afkir mempunyai kandungan zat nutrisi mikro (vitamin, mineral dan asam amino) yang komplit, sehingga dapat menurunkan angka konversi pakan.

Penggantian tepung ikan dengan susu afkir 75\% dalam ransum dapat menurunkan efisiensi penggunaan pakan. Hal tersebut disebabkan karena kandungan nutrisi zat mikro susu afkir seperti vitamin, mineral dan asam amino yang cukup lengkap, selain itu dengan adanya tepung ikan sebanyak 25\% membuat kandungan nutrisi semakin lengkap karena tepung ikan mengandung protein yang cukup tinggi khususnya kandungan lisin dan metionin. Seperti pendapat McDonald et al. (1995) bahwa tepung ikan kaya akan asam amino esensial terutama lisin, sistin, metionin dan thriptophan.

Imbangan komposisi pakan akan memberikan nutrisi yang cukup sesuai yang diperlukan tubuh ayam. Konversi pakan pada kelima perlakuan yang berbeda nyata menunjukkan bahwa susu afkir dapat meningkatkan daya cerna ayam buras. Hal ini sesuai dengan pendapat Anggorodi (1994), bahwa besar kecilnya konversi pakan dipengaruhi oleh daya cerna ternak, kualitas pakan yang dikonsumsi, serta keserasian nilai nutrien yang dikandung pakan tersebut.

\section{Kecernaan Nutrien}

Kecernaan nutrien pada ransum merupakan totak ukur kemampuan ternak memanfaatkan ransum yang diberikan untuk memenuhi kebutuhan ternak, baik untuk hidup pokok maupun pertumbuhan. Pemberian ransum menggunakan penggantian tepung ikan dengan susu afkir berpengaruh terhadap koefisien cerna bahan kering (KCBK). Kecernaan bahan kering ayam buras paling tinggi pada perlakuan $\mathrm{R}_{3}$ adalah 75,08\%. Perlakuan Ro dan R4 menghasilkan kecernaan bahan kering masing-masing $5,98 \%$ dan $4,46 \%$ nyata $(\mathrm{P}<0,05)$ lebih rendah dari perlakuan $\mathrm{R} 3$. Hal tersebut terjadi karena kandungan serat kasar pada perlakuan R3 yaitu 6,86\%, sedangkan perlakuan Ro, R1, R2 dan R4 masing-masing 7,30\%; 7,08\%; 6,98\% dan 6,29\% dikarenakan kombinasi antara tepung ikan dengan susu afkir mampu meningkatkan nilai gizi pakan.

Selain itu, tingginya nilai pada perlakuan $\mathrm{R}_{3}$ disebabkan karena konsumsi ransum yang tinggi mampu membuat daya cerna pakan tinggi, asam amino esensial dalam susu afkir lebih baik, kandungan lisin dan metionin dalam tepung ikan yang sangat diperlukan untuk pertumbuhan ayam, sehingga mampu meningkatkan nilai kecernaan ransum ayam buras. Tillman et al. (1998) melaporkan bahwa kecernaan bahan kering ransum dipengaruhi oleh komposisi kimia bahan penyusun ransum, serat kasar, tingkat protein ransum, bentuk fisik ransum dan jumlah ransum yang dikonsumsi. Sejalan dengan pendapat Ranjhan (1980) yang menjelaskan bahwa tipe dan kuantitas karbohidrat dalam bahan atau penambahannya dalam ransum merefleksikan daya cerna zat-zat makanan lainnya. 
Tabel 2. Kecernaan nutrien ayam buras jantan yang diberi perlakuan penggantian tepung ikan dengan susu afkir dalam ransum umur $2-10$ minggu

\begin{tabular}{|c|c|c|c|c|c|c|}
\hline \multirow{2}{*}{ Peubah } & \multicolumn{5}{|c|}{ Pelakuan $^{1)}$} & \multirow{2}{*}{ SEM $^{2}$} \\
\hline & RO & R1 & $\mathrm{R} 2$ & R3 & R4 & \\
\hline Koefisien cerna bahan kering (KCBK) (\%) & $70,59^{\mathrm{b} 3)}$ & $73,08^{a b}$ & $73,18^{a b}$ & $75,08^{a}$ & $71,73^{b}$ & 0,94 \\
\hline Efisiensi perubahan GE menjadi DE (\%) & $82,57^{\mathrm{bc}}$ & $83,73^{b}$ & $83,22^{b c}$ & $85,80^{a}$ & $81,52^{c}$ & 0,57 \\
\hline Koefisien cerna protein kasar (KCPK) (\%) & $69,68^{a b}$ & $70,06^{\mathrm{ab}}$ & $70,06^{a b}$ & $72,21^{a}$ & $67,81^{b}$ & 1,05 \\
\hline
\end{tabular}

Keterangan :

Perlakuan ransum kontrol tanpa penggantian tepung ikan (R0); penggantian 25\% (R1); penggantian 50\% (R2); penggantian 75\% (R3); penggantian 100\% (R4) Standard Error of the Treatment Mean

Huruf superskrip huruf yang berbeda pada baris yang sama menunjukkan perbedaan yang nyata $(P<0,05)$

Dinyatakan pula bahwa tinggi rendahnya daya cerna zat-zat makanan dalam ransum dapat dipengaruhi oleh laju perjalanan makanan di dalam saluran pencernaan serta kandungan zat-zat makanan yang terdapat di dalam ransum.

Efisiensi perubahan GE menjadi DE ayam buras paling tinggi terjadi pada perlakuan R3 yaitu $85,80 \%$. Hal tersebut disebabkan karena kandungan serat kasar ransum $\mathrm{R}_{3}$ rendah akibatnya daya cerna ransum meningkat dan energi yang dapat dicerna juga meningkat. Lubis (1992) mengatakan bahwa kecernaan dapat menjadi ukuran pertama dari tinggi rendahnya nilai nutrien dari suatu bahan pakan. Bahan pakan dengan kandungan zat-zat pakan yang dapat dicerna tinggi umumnya tinggi pula nutriennya.

Kecernaan protein kasar yang paling tinggi terjadi pada perlakuan R3 yaitu 72,21\% (Tabel 4.3). Perlakuan Ro, R1, dan R2 menghasilkan kecernaan protein ayam buras masing-masing 3,50\%; 2,98\%; dan 2,98\% nyata lebih rendah $(\mathrm{P}<0,05)$ dari perlakuan $\mathrm{R}_{3}$. Hal ini disebabkan karena dapat menunjukkan efisiensi penggunaan protein untuk pertumbuhan ayam serta dapat dilihat dari konversi ransum yang rendah (Tabel 1). Tilman et al. (1998) melaporkan bahwa kecernaan protein dipengaruhi oleh spesies hewan, bentuk fisik ransum dan komposisi bahan makanan. Menurut Okmal (1993) mengatakan bahwa semakin tinggi konsumsi bahan kering ransum, maka konsumsi protein kasar semakin tinggi. Perbedaan nilai kecernaan bahan kering dan protein disebabkan pula oleh adanya perbedaan pada sifat-sifat makanan yang diproses, termasuk kesesuaiannya untuk dihidrolisis oleh enzim pencernaan unggas (Wahju, 2015).

Unggas memiliki keterbatasan dalam mencerna serat kasar karena tidak dapat memproduksi enzim selulase, sehingga serat kasar yang tinggi secara keseluruhan dapat membawa zat-zat makanan yang dapat dicerna keluar bersama feses (Wahju, 2015). Zat makanan yang terdapat di dalam feses dianggap zat makanan yang tidak tercerna sehingga sedikit kandungan protein kasar dalam feses maka nilai kecernaannya semakin baik (Schneider dan Flatt, 1975).

\section{SIMPULAN}

Berdasarkan hasil penelitian diatas maka dapat disimpulkan bahwa penggantian tepung ikan dengan susu akfir $75 \%$ dapat meningkatkan performa dan kecernaan nutrien ayam buras jantan umur $2-10$ minggu.

\section{UCAPAN TERIMAKASIH}

Pada kesempatan ini kami mengucapkan banyak terimakasih kepada Rektor Universitas Udayana, Ketua Progran Studi Ilmu Peternakan Program Pascasarjana Universitas Udayana, dan Dekan Fakultas Peternakan Universitas Udayana dan kedua pembimbing atas fasilitas pendidikan yang diberikan serta bimbingan kepada penulis selama menjalani perkulihaan dan penyusunan tesis.

\section{DAFTAR PUSTAKA}

Alim, M.N., H.D. Sunaryo dan Wurlina. 2012. Pengaruh Pemberian Susu Afkir terhadap Performa Ayam Pedaging Jantan. Skripsi. Fakultas Kedokteran Hewan. Universitas Airlangga. Surabaya

Anggorodi, R. 1994. Nutrisi Aneka Ternak Unggas. PT Gramedia Pustaka Utama, Jakarta.

Ariesta, A.H., I.G. Mahardika dan G.A.M.K Dewi. 2015. Pengaruh level energi dan protein ransum terhadap penampilan ayam buras umur o-10 minggu. Majalah Ilmiah Peternakan. Fakultas Peternakan. Universitas Udayana. Denpasar.

Dewi, G.A.M.K dan I.W. Wijana. 2011. Pengaruh penggunaan level energi ransum terhadap produksi ayam buras. Majalah Ilmiah Peternakan. Fakultas Peternakan. Universitas Udayana. Bali

Gunawan. 2003. Evaluasi Model Pengembangan Usaha Ternak Ayam Buras dan Upaya Perbaikannya. Disertasi. Program Pascasarjana Institut Pertanian Bogor.

Irianto, A. 2011. Pengaruh Pemberian Yoghurt Susu Afkir yang Diperkaya Nata de Coco dalam Mengendalikan Kolesterol Darah Tikus Putih. Fakultas Biologi Universitas Jendral Soedirman. Purwokerto.

Kartadisastra, H.R. 1997. Penyediaan dan Pengelolahan 
Pakan Ternak Ruminansia. Kasinius. Yogyakarta.

Lubis, D.A. 1992. Ilmu Makanan Ternak. Cetakan Kedua. PT Pembangunan. Jakarta

McDonald P, Edwards RA, Greenhalgh JFD dan Morgan CA. 1995. Animal Nutrition. $5^{\text {th }}$ Ed. Singapore (SG): Longman Singapore Publisher Ltd.

Nanda, G.K., H.D.Sunaryo, S.Herman, dan M. Imam. 2012. Pemanfaatan limbah susu afkir sebagai pakan tambahan pada pakan komersial terhadap persentase berat karkas dan lemak abdominal ayam pedaging jantan. Fakultas Kedokteran Hewan. Universitas Airlangga. Surabaya

Okmal. 1993. Manfaat Leguminosa Pohon sebagai Suplemen Protein Dan Minyak Kelapa Sebagai Agensia Defaunasi Dalam Ransum Pertumbuhan Domba. Tesis. Program Pascasarjana. Institut Pertanian Bogor. Bogor.

Pusat Data dan Informasi (Pusdatin). 2015. Perkembangan konsumsi ayam buras.Kementrian Kesehatan Republik Indonesia. Jakarta

Ranjhan, S.K. 1980. Animal Nutrition in the Tropics. Vikas publikasi haouse P. And T. Ltd., New Delhi.

Rasyaf, M. 1995. Pengelolaan Usaha Peternakan Ayam Pedaging. PT. Gramedia Pustaka Utama, Jakarta.
Schneider, B.H. and W.P. Flatt. 1975. The Evaluation Of Freeds Through Digestibility Experiment. The University of Georgia Press. New York. 23-15.

Setiadi, D. 2012. Perbandingan Bobot Hidup, Karkas, Giblet, Dan Lemak Abdominal Ayam Jantan Tipe Medium dengan Strain Berbeda yang Diberi Ransum Komersial Broiler. Fakultas Pertanian. Universitas Lampung. Lampung

Steel, R.G.D. and J.H. Torrie. 1991. Principle and Procedure of Statistic. MsGrow Hill Book Bo. Inc. New York

Tilman, A.D., H. Hari, R. Soedomo, P. Soeharto, Soekamto. 1989. Ilmu Makanan Ternak Dasar. Yogyakarta: Gadjah Mada Univ Press.

Tillman, A. D.; H. Hartadi; S. Reksohadiprodjo; S. Prawirokusumo dan S. Lebdosoekojo. 1998. Ilmu Makanan Ternak Dasar. Cetakan Keenam. Gadjah Mada University Press. Yogyakarta.

Wahju, J. 2015 . Ilmu Nutrisi Unggas. Cetakan Ke enam, Gajah Mada University Press, Yogyakarta.

Zainuddin, D., S.Iskandar dan B. Gunawan. 2000. Pemberian Tingkat Energi dan Asam Amino Esensial Sintetis dalam Penggunaan Bahan Pakan Lokal untuk Ransum Ayam Buras (Generasi II). Laporan Penelitian Balai Penelitian Ternak. Puslitbang Peternakan. Bogor. 